\title{
DEVELOPMENT OF ELECTRONIC COMMERCE IN UKRAINE AND IN THE WORLD
}

\author{
Tetiana Stroiko', Vitaly Burkun², Andrii Mulenko³
}

\begin{abstract}
The purpose of this work is the appropriate use of technology in the life of every business entity, organization, and financial institution. With the growth of technology, the question of their appropriate use has arisen. The state is the key factor of influence and the main body that regulates the activities of innovation and information. The development of the IT sector is the key to sustainable financial development of the country, which contributes to the inflow of finance to the country.

When informatizing society, the main attention is paid to a set of measures aimed at ensuring the full use of reliable, comprehensive and timely knowledge in all human activities. Information technology in the financial sector is a kind of mechanism that provides the whole process of efficient and operational work. After all, the process of economic formation acquires a new meaning. It becomes more productive and more coordinated. In modern conditions, information technologies that provide optimization of activities, integration and communication with the external environment are becoming more widespread and used in today's dynamic market.

Over the past 3 years, the IT sector has become one of the important sectors for the export of services in Ukraine. In 2019, it brought in more than 5 billion USD in exports per year. An increase in the share of exports leads to an increase in the share of GDP, so the development of the IT sector should be a priority for sustainable financial development of the country. Namely, facilitating means the introduction of small and medium-sized IT enterprises. Creating competitive software for finance and accounting, namely EPR and CRM systems, facilitates the management of human resources, assets, supplies, and production of the final product. The world market leaders are such representatives as: Oracle, Salesforce, SAP, QuickBooks, 1C etc. Important areas of using IT technologies are also facilitating the exchange of information in the process of working on projects, accelerating document flow, improving planning efficiency, implementation of general business and marketing strategy, finance, HR-strategy, simplification of brand promotion, interaction with target audience, strengthening control over financial costs, etc. In addition, these systems help to set tasks, deadlines, results.

The paper covers the assessment of the general state of development of e-commerce in Ukraine. The main criteria for the development of information technology are: information services, computer and telecommunications services. The dynamics of foreign trade in these types is highlighted and the most important consumer countries that use the services of Ukrainian specialists in the labor market are studied.
\end{abstract}

Key words: information technology, electronic commerce, CRM system, EPR system, IT sector.

JEL Classification: G14, L81

\section{Introduction}

The 21 st century is one of the turning points in the development of mankind; it is the era of new ideas, information society and new technologies. The advent of the Internet and computer technology in the universallife of mankind has necessitated the processing

\footnotetext{
Corresponding author:

${ }^{1}$ V.O. Sukhomlynskyi National University of Mykolaiv, Ukraine.

E-mail: tanyastroyko@gmail.com

ORCID: https://orcid.org/0000-0002-0044-4651

2 "Tekhnotsentr Mykolaiv-Auto", Ukraine.

E-mail: burkun.v.v@gmail.com

ORCID: https://orcid.org/0000-0002-4318-8483

${ }^{3}$ V.O. Sukhomlynskyi Mykolaiv National University, Ukraine.

E-mail: anmulenko2@gmail.com

ORCID: https://orcid.org/0000-0001-7859-8266
}

of large amounts of information in the shortest possible time and its instantaneous transmission to various parts in the world. Changing modern methods of doing business, a new format of the structure of the economy and competitive advantage in the economic and political capabilities of countries that have been 
technologically and informational developed - those are the changes that lead to such monetization.

Active participation in the international technology market is a guarantee of access to advanced knowledge and productivity of economic processes, as well as knowledge of the international technology market, its formation, structure, current status and major trends are an urgent problem in the economy.

For Ukraine, the IT sector is of particular importance because it should contribute to the general economic and political crisis, it can announce this phenomenon through rapid development, as well as ensure the functioning of many related industries. The Ukrainian IT sphere is an industry that can ensure the development of many components of the national economy, including banking, e-commerce, nanotechnology and many others. It is the IT sector that allows the company to be faster and more flexible in making management decisions, justifying strategic objectives and processing performance indicators.

Today, the rapid growth of information technology has allowed the country to increase the share of gross product in the "IT sector". Technology is entering our lives so rapidly that the use of personal media has become commonplace in the new century. Their influence felt in almost all industrial and scientific fields, in the sphere of social structures, communication between people and much more (Savitska, 2004; Sitnik, 2001).

Information technology has many applications in finance. From trading financial instruments to accounting for personal budgets to reporting business profits, computer technology is used daily by financial companies. Information technology allows you to quickly calculate financial statistics, as well as make electronic money transfers.

\section{The relationship between the financial system and IT-technology}

Financial trade was intensified by information technology. Some computer systems even trade for users. The system programmed to enter buy and sell orders when the stock or bond price reaches a certain level, and automatically closes the order when the target price or stop loss is reached. Computer trading is useful when the trader has a system that allows profitable trading and does not want to enter each order separately (Aristova, 2005). Information technology provides instant information for stock traders to make decisions and allow them to enter orders that are executed immediately. Financial statements also improved through information technology. A language known as XBRL, the extended business reporting language, was used to standardize financial information in the annual reports of state-owned companies. Traders can quickly sort records in this format. They can easily find the statistics needed to determine which companies to invest in. XBRL is based on XML, an extensible markup language used to transmit information over the Internet (Sviderskyi, Pustova, \& Lazariev, 2018).

Financial data can be easily transferred using information technology. Instead of using checks and checking accounts, information technology can instantly clear a transaction. Buying a debit or credit card is quickly compared to the balance on the user's account, which allows the bank to decide whether to allow the transaction. Information technology allows you to carry out operations on weekends and holidays, when the bank has no staff (Pinchuk, 2011).

Personal finance has been simplified with the help of information technology. Banks provide data on check and savings deposits and withdrawals in standardized formats. The customer can download account transactions and save them in records on the home computer. Personal finance software includes additional features, such as charts and reports, which show home users what they spend their money on and where their money comes from.

Information technology is also useful for companies considering financial transactions. Computer systems calculate and display the interest and principal amount of a loan and measure the return on investment when a company borrows money to expand its operations. Companies can securely transfer data over the Internet, and a computer system records all transfers, making it easier to keep accounts.

Technology helps businesses in many ways, which mainly focus on making things bigger, better, or faster than you could without technology. Different industries and companies rely heavily on technology, but some of the benefits of technology in business include improved communications, production optimization, inventory management, and financial record keeping (Voitko, 2012; Ushakova, Plekhanova, 2009).

The importance of technology in society and business can be seen in how technology expands the reach and effectiveness of many forms of internal and external communication.

For example, sales representatives and technicians no longer have to return to the office to receive assignments. Business people who go to work can stay in touch with the office and colleagues, and e-mail allows people to spread messages across geographical boundaries.

Externally, the technology expands the possibilities of marketing communication. Social media, e-mail, mobile phones, and chat features allow companies to communicate faster and more interactively than traditional one-way media options (Sandygei, 2014).

Note, however, that using technology to communicate is not the only solution, and it can be problematic for a business if a certain type of interaction is better facilitated face-to-face. For example, a funeral director 
would not want to rely on impersonal text messages because personal contact is critical at this difficult time in their clients' lives.

\section{The relationship between a business and IT-technology}

No matter what your industry, business size or core business, technology provides opportunities to optimize production beyond what you could produce without it. Small companies can often compete with large firms in operational efficiency through access to high-tech equipment and tools. Manufacturers are constantly striving to upgrade equipment to compete with industry leaders for production efficiency.

CRM and ERP systems are the main types of systems for business management. CRM system designed for the orderly collection and storage of customer information. The system manually or automatically records customer contacts along with other information required for the business. One of the main goals is to simplify the work with clients, making it faster and easier. All communication channels and the entire sales history are located at your fingertips in the CRM interface.

ERP system aimed at organizing both work processes and operations within a company. It used to manage labor resources, assets, supply chain and production of the final product, as well as financial management (Dika, 1996).

This is more serious and heavyweight software. It intended for use primarily in companies with a complex and multi-level production structure.

In the retail business, technology makes the sales and customer service process much more efficient. Scanning barcodes at the checkout is faster than fingerprinting numbers at the checkout. Also, when items are scanned, companies collect important data for accurate marketing and inventory management.

Raw material suppliers, manufacturers, wholesalers, retailers and B2B suppliers have all inventory management processes. The technology used for the systematic organization of items in a warehouse or storage. Comparing computer information with inventory stores helps partners to gather inventory as quickly as possible. Companies can quickly compare inventory when it comes to ordering sizes on a computer screen.

Many inventory processes are automated. For example, retailers often use vendor-driven approaches when vendors automatically send replenishments, when they warn that there are not enough stocks in the store. Organized, effective inventory control helps to minimize inventory costs while meeting consumer demand.

Small and large companies use advanced software to manage accounting and financial tasks. In fact, companies often use programs that synchronize accounting with point of sale terminals and accounting programs, for example, each purchase and sale transaction is automatically recorded on the accounting platform. The use of financial management technology minimizes manual processes, reduces costs and helps to protect against human error.

\section{Information technology in the finances of Ukraine}

In the system of the Ministry of Finance of Ukraine, the highest form of organization of information processing related to the formation and implementation of the state budget with the help of computer technology has become an automated system of financial settlements (ASFS). Precisely the influence of ASFS on the integration of databases in the areas is expanding to cover a large number of functions, namely: analysis and audit, control and reporting (Fedulova, 2006; Fedulova, 2007).

The systems of financial settlements were formed as a hierarchy of one of the links of the financial system and cover all its levels - from districts to the Ministry of Finance of Ukraine. The organizational structure corresponds to the number of regions in Ukraine. The structure itself has three hierarchies on which calculations are automated: From district financial departments. The next stage is the regional financial departments and the ARC. Ministry of Finance of Ukraine provided at national level (Vitlinskyi, Nakonechnyi, \& Sharapov, 2008).

A common feature for the work of the ASFS is the sum of common goals and objectives for the use and management of finances at all levels of the hierarchy. Centralization of payments at the national level has an economically feasible definition of the general directions of formation, distribution and redistribution of financial benefits of the country in the case of maintaining certain proportions. It is with the help of decentralization of calculations at the stage of local budgets that it is possible to give the "green light" to the Council of People's Deputies, taking into account the peculiarities of the design and development of administrative units and their construction.

Exports of the Ukrainian IT industry have grown significantly over the past decade and average $20.7 \%$ (Figure 1.) In 2019, the share of exports in the ICT industry amounted to more than 2.5 billion USD, compared to 2.04 over the previous year. In percentage terms, it grew by more than $21.79 \%$ over the previous year. The main goal of the IT industry is to make a significant contribution to increasing the volume of IT products in the country's economy.

The main consumers of Ukraine's IT services in 2019 remain the Eurozone countries, the United States, Canada, and Israel. In monetary terms, this amounted to almost 2 billion USD (Figure 2). 


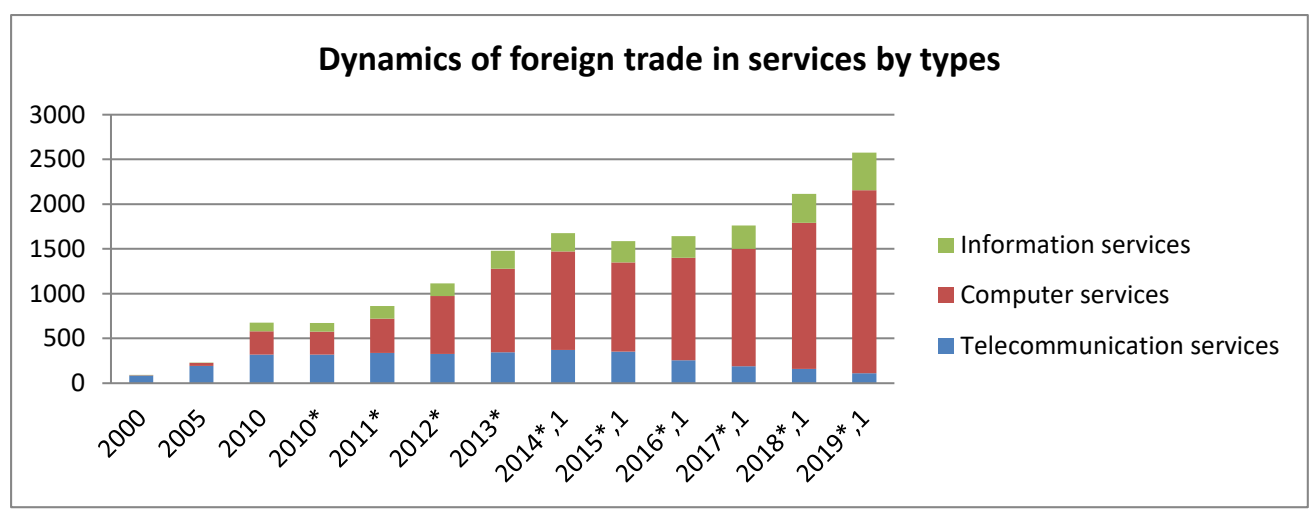

Figure 1. Dynamics of foreign trade of information services by types

Source: based on (State Statistics Service of Ukraine, 2020)

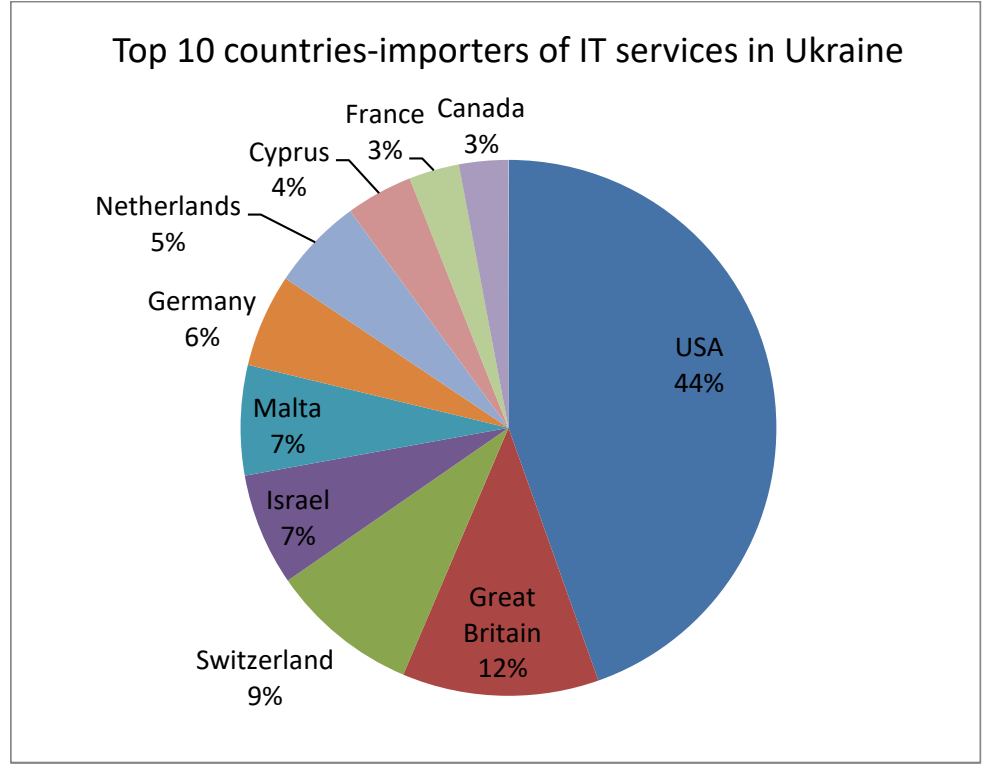

Figure 2. Top countries importers of IT services in Ukraine in 2019

Source: based on (State Statistics Service of Ukraine, 2020)

\section{Conclusions}

Based on our research, various aspects of the use of e-commerce at the macro and micro levels were justified. The efficiency of using the automated system of financial settlements at the level of the Ministry of Finance of Ukraine was investigated.

It was justified that the centralization of payments at the national level was economically feasible provided that certain proportions observed. In particular, the automated system of financial settlements at the level of territorial communities, i.e. at the level of local budgets, will allow to optimize budget processes and provide administrative units. At the same time it must exclude the possibility of any corruption.

The importance of the development of the IT sphere for the Ukrainian economy due to dynamics of growth of exports of information services was proved. In particular, the increase in exports of information services in 2019 compared to the previous period increased by more than $21.79 \%$. At the same time, the main consumers of IT services in Ukraine are the Eurozone countries, the United States, Canada and Israel, providing revenues of about 2 billion USD. It could be concluded that in Ukraine there is a significant impetus in the development of the domestic IT sector. With the help of financial calculations, it is impossible to imagine today that the IT sector does not affect the financial market in the country. ICT has created an effective system of financial settlements, and computer systems help in the calculation of financial transactions (Karmynskyi, Karmynskyi, Nesterov \& Chernykov, 2004; Koryst ukrainskoi IT-haluzi, 2020). High employment in IT leads to a high level of services in this area in the international market. After all, a personal link in 
IT is also the development of software for finance, accounting, e-commerce and close service and monitoring the quality of services.

These problems hinder the development of IT enterprises in Ukraine. The main directions of their development should be:

1. Improving legislation in the field of intellectual property protection and simplifying doing business for the pain of flexible development and attracting additional human resources in IT.

2. Uniform creation of IT enterprises throughout the country, not only in large cities, but also in all regional places, to attract more people to IT.

3. Development of financial software for servicing small and medium enterprises, for more flexible work with finance and accounting in enterprises.

\section{References:}

Aristova, I. (2005). Evolyutsiinyi rozvytok poniattia informatsiina sfera [Evolutionary development of the concept of the information sector]. Visnyk Kharkivskoho natsionalnoho universytetu vnutrishnikh sprav, vol. 31, pp. $239-245$. Dika, V. V. (1996). Informatcionnye sistemy v ekonomike [Information systems in economy]. Moskva: Finansy i statistika.

Fedulova, L. I. (2006). Innovatsiina ekonomika [Information economy]. Kyiv: Lybid.

Fedulova, L. I. (2007). Innovatsiynyy rozvytok promyslovosti Ukrayiny: Tendentsiyi ta zakonomirnosti [Innovation development of Ukrainian industry: Trends and patterns]. Aktualni problemy ekonomiky, vol. 3, pp. 82-95.

Karmynskyi, A. M., Karmynskyi, S. A., Nesterov, V. P., \& Chernykov, B. V. (2004). Informatyzatsiia biznesu: kontseptsii, tekhnolohii, systemy [Business informatization: concepts, technologies, systems]. Moskva: Finansy i statystyka.

Koryst ukrainskoi IT-haluzi (2020) [Benefits of the Ukrainian IT industry]. Available at: http://expres.ua/ news/2016/07/31/196048-koryst-ukrayini-rozvytku-it-galuzi-velychezna (accessed 12 December 2020).

Pinchuk, N. (2011). Informatsiini systemy i tekhnolohii v marketynhu [Information systems and technologies in marketing]. Kyiv: KNEU.

Sandygei, V. (2014). Vplyv informatsiino-komunikatsiinykh tekhnolohii na rozvytok ukrainskoho rynku pratsi [The impact of information and communication technologies on the development of the Ukrainian labour market]. Ukraina: aspekty pratsi, vol. 1, pp. 29-34.

Savitska, H. V. (2004). Ekonomichnyi analiz diialnosti pidpryiemstva [Economic analysis of enterprises]. Kyiv: Znannia.

Sitnik, V. F. (2001). Osnovy informatsiinykh system [Fundamentals of information system]. Kyiv: KNEU.

State Statistics Service of Ukraine (2020). Available at: http://www.ukrstat.gov.ua (accessed 12 December 2020). Sviderskyi, V. P., Pustova, V. V., \& Lazariev, B. O. (2018). Formuvannya ta realizatsiya innovatsiynoyi stratehiyi rozvytku pidpryyemstva [Formation and implementation of innovative strategy of enterprise development]. Ekonomika ta suspilstvo, vol. 16, pp. 468-471.

Vitlinskyi, V. V., Nakonechnyi, S. I., \& Sharapov, O. D. (2008). Ekonomiko-matematychne modeliuvannya [Economic and mathematical modelling]. Kyiv: KNEU.

Voitko, S. V. (2012). Upravlinnia rozvytkom naukomistkykh pidpryiemstv [Development management of knowledge-intensive enterprises]. Kyiv.

Ushakova, I. O., \& Plekhanova, H. O. (2009). Informatsiini systemy ta tekhnolohi na pidpryiemstvi [Information systems and technologies at the enterprise]. Kharkiv: Vyd. KhNEU. 